\title{
Catalogue of \\ Turkish Manuscripts in the \\ Library of Leiden University and Other Collections \\ in the Netherlands
}




\title{
Islamic Manuscripts and Books
}

\author{
Arnoud Vrolijk \\ Leiden University
}

VOLUME 3

The titles published in this series are listed at brill.nl/imb 


\title{
Catalogue of Turkish Manuscripts in the Library of Leiden University and Other Collections in the Netherlands
}

\author{
Minor Collections
}

By

Jan Schmidt

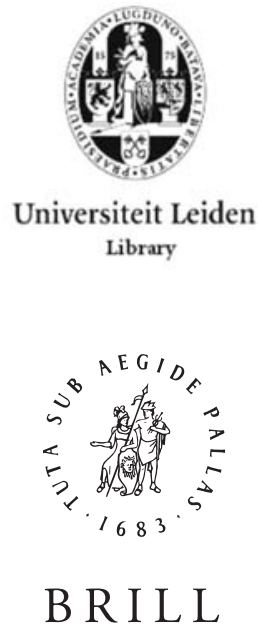

LEIDEN · BOSTON

2012 
The digital edition of this title is published in Open Access.

Cover illustration: Utrecht, UB Hs. 16 B 18, f. 28b. A page of a magnificently produced encyclopaedia of cosmic knowledge by İsmā'îl Ḥaḳkī Erżurumī (d. 1186/1772), copied and designed in Erzurum in $1241 / 1826$, with a schematic drawing of the universe centred on the Kaaba.

LC control no.: 2001372669

This title is co-published with the Leiden University Library as

\section{BIBLIOTHECA UNIVERSITATIS LEIDENSIS}

CODICES MANUSCRIPTI XLI

ISSN 0169-8672, Volume 41

It is also Volume Four in the series Catalogue of Turkish Manuscripts in the Library of Leiden University and Other Collections in the Netherlands.

This publication has been typeset in the multilingual "Brill" typeface. With over 5,100 characters covering Latin, IPA, Greek, and Cyrillic, this typeface is especially suitable for use in the humanities. For more information, please see www.brill.nl/brill-typeface.

ISSN 1877-9964

ISBN 9789004221901 (hardback)

ISBN 9789004221918 (e-book)

Copyright 2012 by Koninklijke Brill NV, Leiden, The Netherlands.

Koninklijke Brill NV incorporates the imprints Brill, Global Oriental, Hotei Publishing, IDC Publishers and Martinus Nijhoff Publishers.

All rights reserved. No part of this publication may be reproduced, translated, stored in a retrieval system, or transmitted in any form or by any means, electronic, mechanical, photocopying, recording or otherwise, without prior written permission from the publisher.

Authorization to photocopy items for internal or personal use is granted by Koninklijke Brill NV provided that the appropriate fees are paid directly to The Copyright Clearance Center, 222 Rosewood Drive, Suite 910, Danvers, MA 01923, USA.

Fees are subject to change.

This book is printed on acid-free paper. 


\section{CONTENTS}

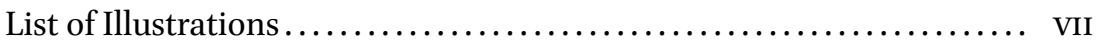

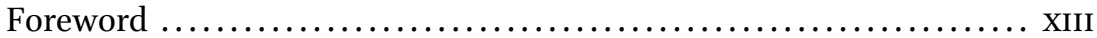

List of Abbreviations..................................... XV

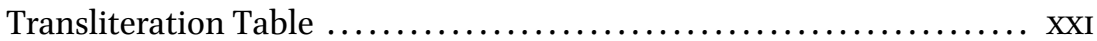

1. Amsterdam, Amsterdam Museum ....................... 1

2. Amsterdam, International Institute of Social History (IISH) ....... 3

3. Amsterdam, Nederlands Scheepvaartmuseum (Netherlands

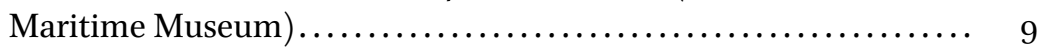

4. Amsterdam, Universiteitsbibliotheek (UB, University Library) ..... 11

5. Groningen, Universiteitsbibliotheek (UB, University Library) ...... $5^{8}$

6. The Hague, Koninklijke Bibliotheek (KB, Royal Library)........... 90

7. The Hague, Museum Meermanno-Westreenianum/Huis van het boek ........................................... 96

8. Leiden, Museum Volkenkunde (Museum of Ethnology, Leiden)..... 100

9. Leiden, Universiteitsbibliotheek (UB, University Library), Bibliotheek A. Hotz (The Hotz Library).................... 108

10. Leiden, Universiteitsbibliotheek (UB, University Library), Bibliotheca Publica Latina (BPL)...

11. Leiden, Universiteitsbibliotheek (University Library), Collection of the Royal Academy of Arts and Sciences (Koninklijke Akademie van Wetenschappen) ............................... 139

12. Leiden, Universiteitsbibliotheek (UB, University Library), Legatum Warnerianum, Addenda ................................ 215

13. Rotterdam, Maritiem Museum (Maritime Museum)............ 258

14. Rotterdam, Wereldmuseum (World Museum) ................ 265

15. Utrecht, Universiteitsbibliotheek (University Library) ......... 273

Epilogue. Turkish Manuscripts in Public Collections in the Netherlands:

A Treasure Trove for the History of Turkish Literary Culture and a

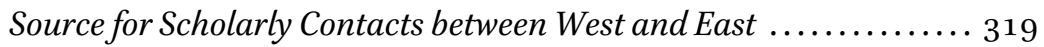

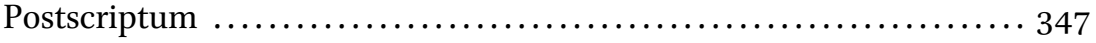

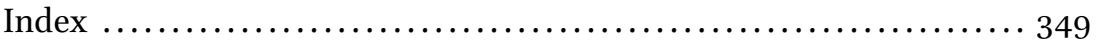

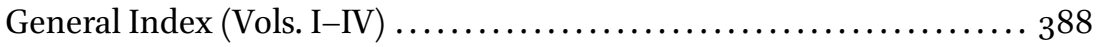


Jan Schmidt - 9789004221918

Downloaded from Brill.come4/26/2023 10:51:52AM via free access 


\section{LIST OF ILLUSTRATIONS}

1. Amsterdam, IIHS, Vâ-Nû Archive 209. Two pages of a passport issued to the writer and journalist, Aḥmed Vâlâ b. Nürüddīn, who used the pen-name of Vâ-Nû, dated 1336 (1920), with photograph of the bearer. ............................... 6

2. Amsterdam, IIHS, Vâ-Nû Archive 179. Letter from Yahya Kemal (Beyatlı), at Warsaw, to Aḥmed Vâlâ b. Nūrüddīn, who used the pen-name of Vâ-Nû, dated 15 September 1928. Sender writes addressee how much he liked his stories; all good writers were always poets first. Nâzım Hikmet had returned from Moscow under arrest. He advises addressee to write to the latter to abandon politics, and live quietly in Istanbul, the most beautiful place on earth. He could become a very good poet if he would refrain from attending and speaking in Communist meetings......

3. Amsterdam, UB Hs. VI H 2, l. A slip of paper with notes on the translation- and copy-work by Shahin Kandi found in a translation by Bobovius of the Book of Isaiah between

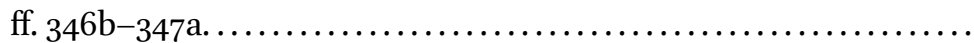

4. Amsterdam, UB Hs. VI H 2, m, f. 10oa. The final page of a translation of the Book of Jeremiah (f. 100a) with a colophon and copyist's verses by Bobovius, made in the 1660 s in Istanbul.

5. Amsterdam, UB Hs. VI H 2, o, f. 1 b. The first page of a neat draft of a translation by Bobovius of the Book of Daniel copied by Shahin Kandi, who was employed by the Leiden orientalist, Jacob Golius, in the 1660 s.

6. Amsterdam, UB Hs. VI H 2. A page of the translation of the Book of Psalms by Bobovius (f. 153a), with a note (in the upper margin) by the copyist Shahin Kandi stating that the passage, indicated by a red line in the left margin, had been corrected.

7. Amsterdam, UB Hs. Cn 12, 13-14a. Two pages from a miscellaneous work with divinatory diagrams, 17 th century....... 30

8. Amsterdam, UB Hs. Cq 48a. A quotation from Lamartine's Le Lac sent by Dāvud Paşa to Frederike Prokesch, née Gossmann, 1868. .. 34

9. Amsterdam, UB Hs. Cq 48a. A photograph of Dāvud Paşa, sent by him to Frederike Prokesch, née Gossmann, $1868 \ldots \ldots \ldots \ldots \ldots \ldots .35$ 
10. Amsterdam, UB Hs. Cq 50. A note concerning the Wallachian tribute for the year $1231\left(1815^{-1816}\right)$ from Hālet Efendi to the

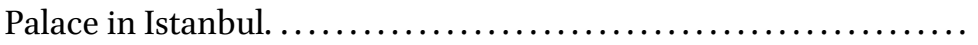

11. Amsterdam, UB Hs. Diederichs 136 G 2. A pass (fermān) issued to Countess Ida Hahn-Hahn for a journey from Istanbul to Izmir, Damascus, Jerusalem and Egypt, and back, dated 1259/1853 ......

12. Amsterdam, UB Hs. Diederichs $136 \mathrm{I}$. A passport issued to a French doctor and colonel called Ciax for a journey to Corfu and Naples, dated 1262/1846.

13. Amsterdam, UB Hs. Diederichs $136 \mathrm{~J}$. The last page of a letter from Tepedelenli 'Alī Paşa to Napoleon, dated 1807 .

14. Amsterdam, UB Hs. Diederichs $136 \mathrm{M}$. The last page of a letter of an Ottoman 'prince', Cigala Paşa, to a friend, written in Brussels, 10 March 1669.

15. Amsterdam, UB Hs. Diederichs 136 N. A letter in French and Turkish from 'Ömer Ag̀a of Lūbīn (Ljubinje) to General Gauthier, commander of the French Dalmatian Army, dated 1812

16. Amsterdam, UB Hs. Dortmond 56 (left) and 291 (right). The upper parts of two rüznämes in scroll-format, 19th-century.

17. Groningen, UB Hs. 471, ff. 147b-148a. Two pages from a collection of pious and magical texts, 18 th century or earlier.

18. Groningen, UB Hs. 474, f. 9a. A page from a miscellany dated 799 (1396-1397) in the second line. The erroneously spelt title of 'Atebetü l-hākāayık, a didactic poem in eastern Turkish by Edīb Ahmed of Yüknek (12th-13th century), is found in the third line. .. 64

19. Groningen, UB Hs. 479, ff. 146b-147a. Two pages from a copy of the Book of Psalms in Italian, Turkish and Dutch, first half of the 18th century or earlier.

20. Groningen, UB Hs. 485, ff. 11b-12a. Two pages from an exercise-book filled by Jacob Christmann; dated $989 / 1582$. On the left is the text of an anonymous treatise on religion, a draft translation into Latin is found in the margin; a transcription of the Turkish text is on the right.

21. Groningen, UB Hs. 487, middle section. Part of a scroll with calligraphic samples, with texts in Arabic, Persian and Turkish,

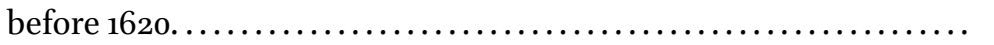

22. Groningen, UB Hs. 489, f. 2a. The 'title page' of a unique, autograph copy of Zihn̄̄ Efendi's Yūsuf $u$ Züleyhā, written in $1024 / 1615$ 
23. Groningen, UB Hs. 490, f. $69 \mathrm{~b}$. The last page of a copy of the Dìvān of Uṣūlì, with an author's inscription by Daniel Widmer of

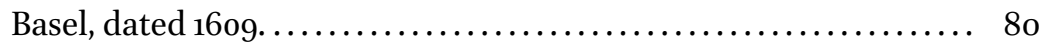

24. Groningen, UB Hs. 491, f. 28a. A ġurre-nāme for the years 1044-1051 (1634-1642) found in a miscellany............... 84

25. Groningen, UB Hs. 491, f. 18(bis)a. An inscription in German of a soldier declaring that he had found the manuscript on, apparently, a battlefield........................... 86

26. The Hague, KB Hs. 130 E 32, f. 68a. Inscription by the Leiden orientalist, Jacob Golius, dated 1639, in an album amicorum compiled by the classicist Gronovius $(1611-1671) \ldots \ldots \ldots \ldots \ldots . . . .291$

27. The Hague, KB Hs. 134 C 44, p. 188. Inscription, with a quotation of a verse by Hāfiz, made by the poet, Willem Bilderdijk, in an album amicorum compiled by the Dutch orientalist, Joannes

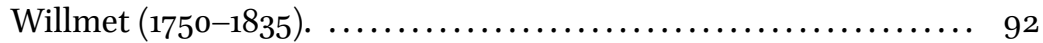

28. The Hague, KB Hs. 135 K 4, f. 11b. Signature and seal of the Ottoman Admiral, Kapudan, Halīl Pasa, dated 1023/1614, found in an album amicorum compiled by Ernst Brinck, secretary to the first Dutch ambassador to the Porte. ................... 93

29. The Hague, Museum Meermanno-Westreenianum Hs. 10 E 30, 1oth flyleaf, verso. Ornate inscription in German, stating that the manuscript had been obtained as war-booty in Hungary in 1687 . . 98

30. The Hague, Museum Meermanno-Westreenianum Hs. 10 E 30, last, recto. Three recipes in Turkish added to a copy of a part of the Koran, 17 th century of earlier.

31. Leiden, Museum Volkenkunde 2871-19. Miniature of 'Sultan Murād' by an anonymous artist, undated................. 101

32. Leiden, Museum Volkenkunde 360-7375. Coloured drawing, $165 \times 105 \mathrm{~mm}$, of a courtier, according to the Dutch caption: 'herald (roeper) of the Sultan', probably 19th-century. 102

33. Leiden, Museum Volkenkunde 360-7424. Coloured drawing, $165 \times 105 \mathrm{~mm}$, of, according to the Dutch caption: 'the Sultan in his former costume', probably 19th-century. ............... 103

34. Leiden, Museum Volkenkunde 36o-7425. Coloured drawing, $165 \times 105 \mathrm{~mm}$, of, according to the Dutch caption: 'the Sultan in his present costume', probably 19th-century. 104

35. Leiden, Museum Volkenkunde 36-9550. A copy of a letter from the Dutch consul at Izmir. Daniel Alexander de Hochepied, to the commander (kapudan) of the Ottoman Fleet, early 18th-century. 
36. Fritz Rudolf Kraus at the entrance of the Department of the Ancient Near East of the Archaeological Museum in Istanbul, with Hittite lion statues (undated photograph, NINO Archive) ... 115

37. Fritz Rudolf Kraus and Hariklia Anastasiadis in Istanbul

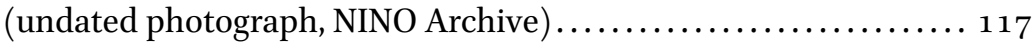

38. Fritz Rudolf Kraus on a ferry in the Bosphorus (undated

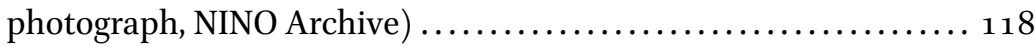

39. Leiden, UB Anhegger 7(11). Meldungsbuch (certificate of enrollment) issued by the University of Vienna in 1932, with photograph of Robert Anhegger. ..................... 253

40. Leiden, UB Anhegger 7(13). First page of a letter from Robert Anhegger to his mother, dated 5 April $1936 \ldots \ldots \ldots \ldots \ldots \ldots \ldots 254$

41a-e. Samples from the collection of late Ottoman cigarette paper booklets, depicting Nasruddin Hoca, a hare (Ch. Dragonis), 'brothers in arms' (silahdaşlar, Penso \& Varon), Hindenburg (Samir Sarrafoglu) and weightlifters. ................... 255

42. Rotterdam, Maritiem Museum H336(3). A visa with a stamp of the Ottoman Consulate in Amsterdam on a passport issued to a Dutch Navy officer, dated 4 June $1870 \ldots \ldots \ldots \ldots \ldots \ldots \ldots \ldots \ldots . \ldots 259$

43. Rotterdam, Maritiem Museum H639, p. 11. Flags depicted in an Ottoman signal book, early 19 th-century. ................. 261

44. Rotterdam, Maritiem Museum H639, p. 47. A page of an Ottoman signal book with explanations of number codes, early

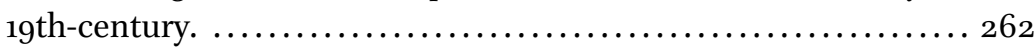

45. Rotterdam, Maritiem Museum H639, p. 338. Lighthouse codes with explanations found in an Ottoman signal book, early 19 th

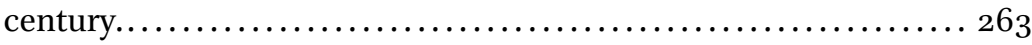

46. Rotterdam, Wereldmuseum 6o948. A miniature depicting the murder of 'Alī by Ibn Muljam, 16th century, taken from Fużūlī's

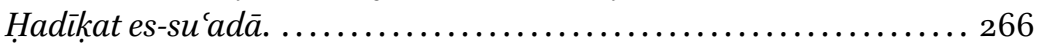

47. Rotterdam, Wereldmuseum 63215. The upper part of a copy of the 'ahdnāme of 1027/1618, granted to the Venetian Republic..... 268

48. Rotterdam, Wereldmuseum 70935. The first page of a magnificently illuminated copy of Fużūlī's Dìvān, undated. . 270

49. Utrecht, UB Hs. 1 B 8, f. 225b. The first page of a manuscript with a translation of al-Maqrīzì's Khitaț, with tailed signatures and an explanation by Christianus Ravius that he had borrowed the book from an owner in Istanbul for an edition in 1640 . 
50a-b. Utrecht, UB Hs. 1 B 8, ff. 24a-23b. Two pages from a translation of al-Maqrīzì's Khitat, showing the work of two different copyists; the catchword on the right suits the first word on the following page on the left............................ 276

51. Utrecht, UB Hs. 16 B 14, f. 7a. A page from a collection of religious parables, copied in $1222(1807-1808)$, with a heading of the parable of Kesik-baş ('severed head'). .................... 284

52. Utrecht, UB Hs. 16 B 18, f. 15b. The first page from a magnificently produced encyclopaedia of cosmic knowledge by İsmācîl Haḳḳ̄ Erżurumī (d. 1186/1772), copied and designed in Erzurum in

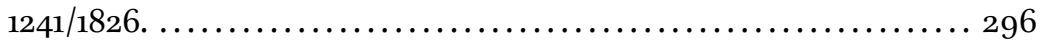

53. Utrecht, UB Hs. 16 B 18, f. 28b. A page from a magnificently produced encyclopaedia of cosmic knowledge by İsmācîl Haḳḳ̄ Erżurumī (d. 1186/1772), copied and designed in Erzurum in $1241 / 1826$, with a schematic drawing of the universe centred on the Kaaba.

54. Utrecht, UB Hs. 16 B 18, f. 317 b. A page from a magnificently produced encyclopaedia of cosmic knowledge by İsmāōil Haḳḳ̄ Erżurumī (d. 1186/1772), copied and designed in Erzurum in $1241 / 1826$, with a plan of the house of the author's shaykh, İsmāicl Tillovì. 298

55. Utrecht, UB Hs. 16 B 18, f. 349 b. The final page of a letter of advice to a 'bother' appended to a magnificently produced encyclopaedia of cosmic knowledge by İsmācîl Haḳḳ̄ Erżurumī (d. 1186/1772), copied and designed in Erzurum in 1241/1826..... 299

56. Utrecht, UB Hs. $16 \mathrm{C}$ 1, p. 51 . A page from a collection of original letters and documents, showing a report (by the ḳahvecibaşı of the Palace, Sa'dullāh) and a hüküm concerning the purchase of wheat and barley in Sīrūz (Serre), with bureaucratic annotations,

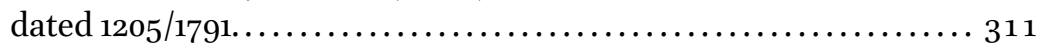

57. Utrecht, UB Hs. 16 C 1, p. 89. A page from a collection of original letters and documents, showing a petition and a legal report concerning a conflict about the repair of a building near the quay of Davudpaşa, Istanbul, preceded by bureaucratic annotations, dated 1208 (1793-1794) ..................................... 312

58. Utrecht, UB Hs. 16 C 1, p. 132. A page from a collection of original letters and documents, showing a statement of the Venetian ambassador, surrounded by bureaucratic annotations, on the shipwreck of a Venetian vessel off Limnos which had been on its way to Istanbul with grain, dated $1205 / 1791 . \ldots \ldots \ldots \ldots \ldots \ldots \ldots \ldots \ldots \ldots$ 
59. Utrecht, UB Hs. 16 C 1, p. 131. The verso side of the previous document, with a copy of a report of the gümrük emini of Istanbul on the same affair, dated 1205/1791.

6o. Utrecht, UB Hs. 16 C 2, p. 13. A page from a collection of original letters and documents, showing a copy of a private letter from the mother of the Ottoman rebel Țayyār Paşa to her brother,

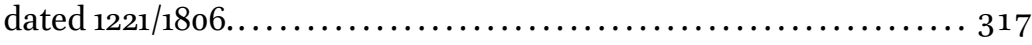

61. Utrecht, UB Hs. 16 C 2, p. 17. A page from a collection of original letters and documents, showing a report on the purchase, shipment and eventual loss of a load of grain sent from the Mora (Peloponnese) to Istanbul, preceded by bureaucratic annotations, dated 1204-1205 (1789-1791).................. 318 


\section{FOREWORD}

The present volume is the fourth and final in a series that describe the Turkish manuscripts kept in Dutch public collections with the exception of archives. The first three volumes were published by the Leiden University Library in the years 2000, 2002 and 2006. They describe the Turkish manuscripts kept in the main Oriental collection in the Leiden University Library, the so-called Legatum Warnerianum, which came, so to speak, to life in 1665 with the bequest of Levinus Warner (described in the first volume). The Legatum, although the most voluminous collection of handwritten Oriental and Turkish texts in the Netherlands, is not the only one. There is more. Smaller collections of between only one up to a few dozens of items are kept in both the Leiden library and libraries in Amsterdam, Groningen, The Hague, Leiden, Rotterdam and Utrecht. These smaller collections are described in this volume. Inevitably, mistakes have been made in the past. I took the opportunity to repair here one of them that concerns the oversight of some Turkish texts in the Legatum. These are described in chapter 9. This chapter also contains descriptions of items that came to light or were acquired after the publication of the first three volumes. The chapters on the various collections is concluded by an 'Epilogue' that presents an assessment of the Dutch Turkish collection as a whole. The book is concluded with a general index which covers all four volumes.

The manuscript of the book was completed in 2003, but for various reasons, its publication was postponed until now. I would also like to take here the opportunity to show my gratitude to the staff of the Leiden University Library, and in particular to the, by now retired, keeper of the Leiden Oriental collection, Jan Just Witkam, who took the initiative to organize the cataloguing project. Personnel of the other libraries in the Netherlands covered in this book were without exception extremely helpful in giving me access to their treasures. I also thank the Dutch Research Fund $(N W O)$ which financed the cataloguing project. A final word of thanks goes to my colleagues Hans Theunissen and Machiel van Crevel who gave the final push that made the publication of this book possible (and inspired me to return to my cataloguing work and resume the thread which I had left dangling about a decade ago) and to Ingrid Heijckers-Velt of Brill's who helped me in the last phase of this publication. 
Jan Schmidt - 9789004221918

Downloaded from Brill.come4/26/2023 10:51:52AM via free access 


\section{LIST OF ABBREVIATIONS}

Van der Aa

Aumer

Ateş

b.

besmele

Blaškovičs

$B L K O$

$B N B$

$B N W$

Blochet

Brugmans, Catalogus

BSOAS

Catalogue 1696

$C C A$

$\mathrm{CCO}$

CCOBARS

Churchill

Cods.
A.J. van der Aa et al. Biographisch Woordenboek der Nederlanden. Revised ed. 21. Vols. Haarlem ?-1878. I. Aumer, Verzeichnis der orientalischen Handschriften der K. Hof-und Staatsbibliothek in München (Türkische Handschriften). Munich 1875.

Ahmed Ateş, Istanbul kütüphanelerinde Farsça manzum eserler I. Istanbul 1968.

ibn, bin (son of)

bismi llāhi r-rahmmāni rahīm

Jozef Blaškovičs, Arabische, türkische und persische

Handschriften der Universitäts-bibliothek in Bratislava.

Bratislava 1961.

Biographisches Lexicon des Kaiserthums Oesterreich. 59

Vols. Vienna 1856-189o.

Biographie Nationale publiée par l'Académie Royale de Belgique. $1866 \mathrm{ff}$.

Biografisch Woordenboek van Nederland. 4 Vols., The

Hague 1979-1994.

E. Blochet, Bibliothèque Nationale. Catalogue des manuscrits turcs. 2 Vols., Paris 1932-1933.

H. Brugmans, Catalogus Codicum Manu Scriptorum.

Groningen 1898 .

Bulletin of the School of Oriental and African Studies.

Catalogus Insignium in omni facultate linguisque,

Arabica, Persica, turcica, Chinense \&c. librorum M.SS. quos Doctissimus Clarissimus Vir D. Jacobus Golius ... collegit quorum auctio habebitur in Aedibus Johannis du Vivie ... Ad diem XVI Octobris ... Leiden 1696.

M.J. de Goeije \& M.Th. Houtsma, Catalogus Codicum Arabicorum Bibliothecae Academiae Lugduno-Bataviae. 2 Vols., Leiden 1888 \& 1907.

R. Dozy, P. de Jong et alii, Catalogus Codicum Orientalium Bibliothecae Lugduno-Batavae. 6 Vols., Leiden 1851-1877.

P. de Jong, Catalogus Codicum Orientalium Bibliothecae Academiae Regiae Scientiarum. Leiden 1862.

W.A. Churchill, Watermarks in Paper in Holland,

England, France etc., in the XVII and XVIII Centuries and their Interconnection. Amsterdam 1935.

Codices 
$\operatorname{col}(\mathrm{s})$

d.

Danişmend, Kronoloji

$D B F$

Divanlar

$D N B$

$E I^{1}$

$E I^{2}$

Ethé

Fihris

Fleischer

Flemming

Flügel

$G A L$

GOD

Gölpınarlı

GOR

Götz I, II

GOW

De Groot, Ottoman

Empire

Heawood column(s)

died

İsmail Hâmi Danişmend, İzahlı Osmanlı tarihi kronolojisi. 2nd ed. 5 Vols., Istanbul 1971-1972.

Dictionnaire de biographie française I ff. Paris $1933 \mathrm{ff}$. İstanbul kitaplıkları Türkçe yazma divanlar kataloğu. 3 Vols., Istanbul 1947, 1959 \& 1965.

Dictionary of National Biography. London $1885 \mathrm{ff}$.

Encyclopaedia of Islam. 1st ed. M.T. Houtsma, T.W.

Arnold et alii, eds. 4 Vols., Leiden \& London, 1912-1942.

Encyclopaedia of Islam. 2nd ed. H.A.R. Gibb, J.H.

Kramers et al. 8 Vols., Leiden \& London 1954-.

Hermann Ethé, Catalogue of the Persian, Turkish, Hindûstânî and Pushtû Manuscripts in the Bodleian Library II. Oxford 1930.

Fihris al-makhțūtāt al-Turkīya al-'Uthmānīya. 4 Vols., Cairo 1987-1992. (A Survey of the Ottoman and Turkish Manuscripts of the Dār al-Kutub al-Qawmīya at Cairo) Henricus Orthobius Fleischer, Catalogus Codicum Manuscriptorum Orientalium Bibliothecae Regiae Dresdensis. Leipzig 1831.

Barbara Flemming, Türkische Handschriften. Wiesbaden 1968. (Verzeichnis der orientalischen Handschriften in Deutschland, XIII, 1)

Gustav Flügel, Die arabischen, persischen und türkischen Handschriften der k.-k. Hofbibliothek zu Wien. 3 Vols., Vienna $1865^{-1867 .}$

Carl Brockelmann, Geschichte der arabischen Literatur. 2nd ed. 2 Vols. Leiden 1946-1949; Suppl. 3 Vols., Leiden 1937-1942.

Joseph von Hammer, Geschichte der osmanischen Dichtkunst. 4 Vols., Pest 1836-1838.

Abdülbâki Gölpınarlı, Mevlânâ Müzesi Yazmalar

Kataloğu. 2 Vols., Ankara 1967-1972.

Joseph von Hammer, Geschichte des osmanischen Reiches. 10 Vols., Pest 1827-1835.

Manfred Götz, Türkische Handschriften. 2 Vols.

Wiesbaden 1968 \& 1979. (Verzeichnis der orientalischen Handschriften in Deutschland, III, 2 \& XIII, 4)

Franz Babinger, Die Geschichtsschreiber der Osmanen und ihre Werke. Leipzig 1927.

A.H. de Groot, The Ottoman Empire and the Dutch Republic. A History of the Earliest Diplomatic Relations 1610-1630. Leiden 1978.

Edward Heawood, Monumentae Charta Papyraceae I, Watermarks. Hilversum 1950. 
Heeringa, Bronnen

HOP

Houtsma, Correspondentie

$\dot{I} A$

İnal

JNES

Juynboll, Beoefenaars

Karabulut

Karatay

Kashfaż-Żunūn

KIYK

Kut

Kut, Manisa

Levend

Majda

Medical Manuscripts

Minorsky

MS(S)

NA LH
K. Heeringa ed., Bronnen tot de geschiedenis van den Levantschen handel I (1590-1660) \& II (1661-1726). The Hague 1910 \& 1917.

E.J.W. Gibb, A History of Ottoman Poetry. 6 Vols., London 1900-1909.

M.Th. Houtsma, 'Uit de Oostersche correspondentie van Th. Erpenius, Jac. Golius en Lev. Warner. Eene bijdrage tot de geschiedenis van de beoefening der Oostersche letteren in Nederland'. Verhandelingen der Koninklijke Akademie van Wetenschappen, Afdeeling Letterkunde 17, 116 pp. Amsterdam 1887.

İslâm Anseklopedisi. 12 Vols., Istanbul 1940-1978.

İbnülemin Mahmud Kemal İnal, Son Asır Türk Şairleri. 2nd impr., 4 Vols. Istanbul 1969-1971.

Journal of Near Eastern Studies (Chicago)

Wilhelmina Cornelia Juynboll. Zeventiende-eewsche Beoefenaars van het Arabisch in Nederland. Utrecht 1931. Ali Rıza Karabulut, Kayseri Râşid Efendi Kütüphanesindeki Türkçe, Farsça, Arabça Yazmalar Kataloğu. Kayseri 1982.

Fehmi Edhem Karatay, Topkapı Sarayı Müzesi Küphanesi Türkçe Yazmalar Kataloğu. 2 Vols., Istanbul 1961.

Gustavus Fluegel, ed., Lexicon Bibliographicum et Encyclopaedicum a Mustafa ben Abdallah KatibJelebi dicto. 6 Vols., Leipzig \& London $1835^{-18} 5^{2}$.

Ramazan Şeşen, Mustafa Haşim et al., Kıbrıs İslâm Yazmaları Kataloğu. Istanbul 1995.

Günay Kut, Tercüman Gazetesi Kütüphanesi Türkçe Yazmalar Kataloğu I. Istanbul 1989.

Günay Kut Alpay, 'Bursa ve Manisa İl-Halk kütüphanelerindeki bazı Türkçe Yazmalar üzerine', in Journal of Turkish Studies I (1977), pp. 121-147.

Agâh Sırrı Levend, Türk Edebiyatı Tarihi I. Giriş. Ankara 1973.

T. Majda, Katalog Rekopisów Tureckich i Perskich. Warsaw 1968.

Ramazan Şeşen, Cemil Akpınar \& Cevad İzgi, Catalogue of Islamic Medical Manuscripts (in Arabic, Turkish \& Persian) in the Libraries of Turkey. Istanbul 1984 (text in Arabic).

V. Minorsky. The Chester Beatty Library. A Catalogue of the Turkish Mansucripts and Miniatures. Dublin 1958.

Manuscript(s)

Nationaal Archief (National Archives, The Hague), (first department) collection 'Directeuren der Levantsche Handel' 
NA LT

NA SG

Nallino

Nanninga, Bronnen

Nat, 'Studie'

$N N B W$

$O A$

$\ddot{O B} L$

$' O M$

Özege

Pertsch

Pertsch (Berlin)

PhTF

Représentants

Rieu

Rossi

Rypka

Sachau \& Ethé

Sarajevo

SBL
Nationaal Archief (National Archives, The Hague), (second department) collection 'Legatie Turkije en de Levant'

Nationaal Archief (National Archives, The Hague), (first department) collection 'Staten-Generaal'

Carlo Alfonso Nallino, I manoscritti Arabi, Persici, Siriaci e Turchi della Biblioteca Nazionale e della R. Accademia delle scienze di Torino. Turin 1900.

J.G. Nanninga, Bronnen tot de geschiedenis van den Levantschen handel III (1727-1764) \& IV (1765-1826). The Hague 1964, 1968.

Jan Nat, 'De studie van de oostersche talen in Nederland in de $18 \mathrm{e}$ en $19^{\mathrm{e}}$ eeuw'. Diss. Purmerend 1929.

P.C. Molhuysen, P.J. Blok et alii, Nieuw Nederlandsch Biografisch Woordenboek. 10 Vols., Leiden 1911-1937. Osmanlı Araştırmaları/The Journal of Ottoman Studies. Österreichisches Biographisches Lexicon 1815-1950. Graz \& Cologne $1957 \mathrm{ff}$.

Brusalı Mehmed Tahir, 'Oșmānlı mü'ellifleri. 3 Vols., Istanbul 1334-1343.

M. Seyfettin Özege, Eski harflerle basılmış Türkçe eserler kataloğu. 5 Vols., Istanbul 1971-1979.

W. Pertsch, Die orientalischen Handschriften der Herzoglichen Bibliothek zu Gotha II: Die Türkischen Handschriften. Vienna 1864.

W. Pertsch, Verzeichnis der türkischen Handschriften der Königlichen Bibliothek zu Berlin. Berlin 1889.

Philologiae Turcicae Fundamenta. 2 Vols. Wiesbaden 1959 \& 1964.

Jean-Louis Bacqué-Grammont, Sinan Kuneralp et al., Représentants permanents de la France en Turquie (1536-1991) et de la Turquie en France (1797-1991). Paris \& Istanbul 1991.

Charles Rieu, Catalogue of the Turkish Manuscripts in the British Museum. London 1888.

E. Rossi, Elenco dei manuscritti turchi della Biblioteca Vaticana. Vatican City 1953.

Jan Rypka, History of Iranian Literature. Karl Jahn, ed. Dordrecht 1968.

Ed. Sachau \& Hermann Ethé, Catalogue of the Persian, Turkish, Hindûstânî and Pushtû Manuscripts in the Bodleian Library I. Oxford 1889.

Kasim Dobrača, Fehim Nametak et alii, Gazi Husrev-

Begova Biblioteka u Sarajevu; Katalog Arapskih,

Turskih i Perzijskih Rukopisa. 6 Vols. Sarajevo 19631999.

Svenskt Biografiskt Lexikon. I ff. Stockholm $1918 \mathrm{ff}$. 
Schmidt

Schmidt, 'Heyman Papers'

Schmidt, Legation Window

Schmidt, Opium Trade

Schmidt, Pure Water

Schmitz

Schutte, Repertorium

Schutte (1983)

Şeşen

$S^{\prime} O$

$S^{\prime} O^{2}$

Sohrweide I, II

Storey

$T A$

Taeschner, Geographische Literatur TDVIA

Tornberg

Tornberg (Lund)
Jan Schmidt, A Catalogue of the Turkish Manuscripts in the John Rylands University Library at Manchester. Leiden \& Boston 2011.

Jan Schmidt, 'An Ostrich Egg for Golius. The Heyman Papers preserved in the Leiden and Manchester University Libraries and Early-modern Contacts between the Netherlands and the Middle East', in Jan Schmidt, The Joys of Philology; Studies in Ottoman Literature, History and Orientalism (1500-1923) II, 8-74. Istanbul 2002.

Jan Schmidt, Through the Legation Window 1876-1926. Four Essays on Dutch, Dutch-Indian and Ottoman History. Istanbul 1992.

Jan Schmidt, From Anatolia to Indonesia. Opium Trade and the Dutch Community of Izmir, 1820-1940. Istanbul 1998.

Jan Schmidt. Pure Water for Thrsty Muslims; A Study of Muștafā 'Ālī of Gallipoli’s Künhül-ahbār. Leiden 1992. Barbara Schmitz, Islamic Manuscripts in the New York Public Library. New York \& Oxford 1992.

O. Schutte, Repertorium der Nederlandse vertegenwoordigers residerende in het buitenland 1584-1810. The Hague 1976.

O. Schutte, Repertorium der buitenlandse vertegenwoordigers residerende in Nederland 1584-1810. The Hague 1983.

Ramazan Şeşen, Cevat İlgi and Cemil Akpınar, Catalogue of Manuscripts in the Köprülü Library. 3 Vols., Istanbul 1986.

Mehmed Süreyyā, Sicill-i 'Oșmān̄̄ 4 Vols., Istanbul 1308-1315.

Mehmed Süreyya, Sicill-i osmanî. Osmanlı ünlüleri. Nuri Akbayar \& Seyit Ali Kahraman, ed. 6 Vols., Istanbul 1996. Hanna Sohrweide, Türkische Handschriften. Wiesbaden 1974 \& 1981. (Verzeichnis der orientalischen Handschriften in Deutschland, XIII, 3 \& XIII, 5)

C.A. Storey, Persian Literature: A Bio-bibliographical Survey. 7 Vols. London \& Leiden 1925-1992. Turkologischer Anzeiger I ff. Vienna $1975 \mathrm{ff}$. Franz Taeschner, 'Die geographische Literatur der Osmanen'. ZDMG 2/77 (1923), pp. 31-80. Türk Diyanet Vakfi İslam Ansiklopedisi I ff. $1988 \mathrm{ff}$. C.J. Tornberg, Codices Arabici, Persici et Turcici Bibliothecae Regiae Universitatis Upsaliensis. Upsala 1849 .

C.J. Tornberg, Codices Orientales Bibliothecae Regiae Universitatis Lundensis. Lund $185^{\circ}$. 
TTY

TYTK (Adana)

TYTK (Adıyaman)

TYTK (Ankara, Cumhurbaşkanlığı

TYTK (Antalya)

TYTK (Çankırı)
Istanbul Kütüphaneleri Tarih-Coğafya Yazmaları Kataloğları. I. Türkçe Tarih Yazmaları Istanbul 1943-1962.

Türkiye Yazmaları Toplu Kataloğu/ The Union Catalogue of Manuscripts in Turkey. Adana İl Halk Kütüphanesi ve Müzesi, o1. Ankara 1979.

Türkiye Yazmaları Toplu Kataloğu/ The Union Catalogue of Manuscripts in Turkey, 02. Ankara 1979. Türkiye Yazmaları Toplu Kataloğu/ The Union Catalogue of Manuscripts in Turkey, o6, pp. 13-25. Ankara 1979. Türkiye Yazmaları Toplu Kataloğu/ The Union Catalogue of Manuscripts in Turkey, 05. 5 Vols. Istanbul 1982-1984. Türkiye Yazmaları Toplu Kataloğu/ The Union Catalogue of Manuscripts in Turkey, Çankırı İl Halk Kütüphanesi Yamalar Karaloğu. Ankara 1998.

TYTK (Giresun, Rize, Ordu)

Türkiye Yazmaları Toplu Kataloğu/ The Union Catalogue of Manuscripts in Turkey, o6. Ankara 1980.

TYTK (Süleymaniye, Türkiye Yazmaları Toplu Kataloğu/The Union Catalogue Mustafa Âşir Efendi) of Manuscripts in Turkey, 34/iv. Ankara 1994.

TYTK (Süleymaniye, Ali Nihat Tarlan)

TYTK (Türkiye Büyük Millet Meclisi)

UB

Umur

Voorhoeve

Warner and his Legacy

Weijers, Orientalia

Yardım

Zambaur

$Z D M G$
Türkiye Yazmaları Toplu Kataloğu / The Union Catalogue of Manuscripts in Turkey, 34. Ankara 1981.

Türkiye Yazmaları Toplu Kataloğu / The Union Catalogue of Manuscripts in Turkey, 06, pp. 29-72. Ankara 1979. University Library

Süha Umur, Osmanlı Padişah Tuğraları. Istanbul 1980. P. Voorhoeve, Handlist of Arabic Manuscripts (Bibliothecae Universitatis Leidensis Codices Manuscripti VII). The Hague, Boston \& London 1980.

Levinus Warner and his Legacy. Three Centuries Legatum Warnerianum in the Leiden University Library. Catalogue of the Commemorative Exhibition in the Bibliotheca Thysiana from April 27th till May 15th 1970. Leiden 1970. Henricus Engelinus Weijers, 'Commentarii de Codicibus Manuscriptis Orientalibus Bobliothecae Leidensis'. T.G.J. Juynboll, T. Roorda \& H.E. Weijers, Orientalia I, pp. 297-504. Amsterdam 1840.

Ali Yardım, Izmir Millî Kütüphanesi Yazma Eserleri Kataloğu. 4 Vols. Izmir 1992-1997.

E. von Zambaur, Manuel de généalogie pour l'histoire de l'Islam. Hanover 1927.

Zeitschrift der Deutschen Morgendländischen Gesellschaft (Leipzig-Stuttgart). 
TRANSLITERATION TABLE

\begin{tabular}{|c|c|c|c|c|}
\hline letter & general & Arabic & Persian & Turkish \\
\hline i & ', à & & & \\
\hline ب ب & $\mathrm{b}$ & & & \\
\hline " & $\mathrm{p}$ & & & \\
\hline ت & $\mathrm{t}$ & & & \\
\hline$\dot{H}$ & th & th & th & $\underline{\mathbf{S}}$ \\
\hline ة & & $\mathrm{t}$ & & \\
\hline ج & & $\mathrm{j}$ & $\mathrm{j}$ & $\mathrm{c}$ \\
\hline そ & & & ch & Ç \\
\hline 乙 & ḥ & & & \\
\hline$\dot{乙}$ & & $\mathrm{kh}$ & $\mathrm{kh}$ & $\stackrel{h}{-}$ \\
\hline خوا & & & $\mathrm{kh}^{w} \overline{\mathrm{a}}$ & hyō \\
\hline د & $\mathrm{d}$ & & & \\
\hline ذ & $\mathrm{dh}$ & $\mathrm{dh}$ & $\mathrm{dh}$ & $\underline{\mathrm{z}}$ \\
\hline ر & $\mathrm{r}$ & & & \\
\hline j & $\mathrm{z}$ & & & \\
\hline j & & & $\mathrm{zh}$ & $\mathrm{j}$ \\
\hline س س & $\mathrm{s}$ & & & \\
\hline ش & & sh & sh & Ş \\
\hline ص & ș & & & \\
\hline ض ض & d & $\mathrm{d}$ & d & $\dot{\mathrm{z}}$ \\
\hline b & $\mathrm{t}$ & & & \\
\hline ظ & $\mathrm{z}$ & & & \\
\hline$\varepsilon$ & ' & & & \\
\hline $\bar{\varepsilon}$ & & gh & gh & $\dot{\mathrm{g}}$ \\
\hline ف & $\mathrm{f}$ & & & \\
\hline ق ق & & $\mathrm{q}$ & $\mathrm{q}$ & $\mathrm{k}$ \\
\hline ك) & & $\mathrm{k}$ & $\mathrm{k}, \mathrm{g}$ & $\mathrm{k}, \mathrm{g}$ \\
\hline 」 & l & & & \\
\hline P & $\mathrm{m}$ & & & \\
\hline ن & $\mathrm{n}$ & & & \\
\hline 9 & & $\overline{\mathrm{u}}, \mathrm{w}$ & $\overline{\mathrm{u}}, \mathrm{w}$ & $\mathrm{o}, \ddot{\mathrm{o}}, \mathrm{u}, \overline{\mathrm{u}}, \ddot{\mathrm{u}}, \mathrm{v}$ \\
\hline هـ & & $\mathrm{h}$ & $\mathrm{h}$ & $\mathrm{h}, \mathrm{a}, \mathrm{e}$ \\
\hline ي & $\mathrm{y}, \overline{\mathrm{l}}$ & & & \\
\hline$\checkmark$ & & $\overline{\mathbf{l}}, \overline{\mathrm{a}}$ & $\overline{\mathbf{1}}, \overline{\mathrm{a}}$ & $\overline{\mathbf{1}}, \mathrm{i}, \mathrm{l}, \overline{\mathrm{a}}$ \\
\hline
\end{tabular}

